PRZEGLĄD BIBLIOTECZNY 2019 z. 3

PL ISSN 0033-202X

ARTUR ZNAJOMSKI

Institute of Information and Library Science

UMCS in Lublin

e-mail: aznajomski@o2.pl

\title{
DOCUMENTS OF PERSONAL LIFE IN PERSONAL BIBLIOGRAPHIES. EXPLORATORY RESEARCH
}

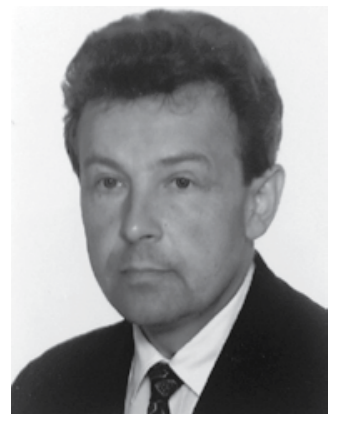

Artur Znajomski dr hab. works at the Institute of Information and Library Science of the Maria Curie-Skłodowska University in Lublin. The main current of his research interests are issues of personal and local bibliographies in Poland. Major publications include: Personal bibliographies of Polish historians (Lublin 2004); "Bibliographies of personal teams - institutions, status and needs". In: Bibliography: theory, practice, didactics. Ed. J. Woźniak-Kasperek, M. Ochmański (Warszawa 2009); "The influence of the Lviv historical environment on the development of the methodology of personal bibliography until 1939". In: Multicultural historical environment of Lviv in the 19th and 20th centuries Vol.5. Ed. J. Maternicki and L. Zaszkilniak (Rzeszów, 2007); "Special bibliographies - development trends on the example of personal bibliographies". In: Fifth National Council of Bibliographers (Warszawa 2004); "The state of local bibliographies in Poland after World War II". In: Around the Book, the Library and Information. Ed. M. Juda (et al.) (Lublin, 2014); "Information efficiency of local bibliographies published in Poland in the years 1945-1989". In: Dymmel A., Kotuła S. D., Zawodomski A.; Reading and information culture - theory and practice. Selected issues (Lublin 2015); "An outline of the development of Polish local bibliographies until 1939". In: Bibliografia. History, theory, practice. Ed. J. Franke, J. Woźniak-Kasperek (Warszawa 2016). He is the author and co-author of a number of bibliographic studies, including "Bibliography of publications of prof. dr hab. Barbara Trelińska for the years 1973-2012". In: Between text and sign (Warszawa, 2013), and is co-editor of the Bibliography of the city of Świdnik until 2003 (Świdnik, 2004).

KEYWORDS: Personal bibliographies. History. Material selection. Personal life documents 
ABSTRACT: Theses/purpose of the article - The main purpose of the article is to present the selection of personal life documents in personal bibliographies, published in Poland until 1985. Research methods - The method of analysis and criticism of personal bibliographies was used, paying attention to the selection of material, in particular the registration of personal life documents. Results and conclusions - The research undertaken shows that personal bibliographies published prior to 1985 include various types of personal life documents, but only a small part of them do so. The vast majority of the analyzed material omit such documents, although they are an extremely important source of information in scientific research, particularly useful to other fields, for example biographical studies. Personal bibliographies should record personal life documents to a much greater extent, not only those published but also in manuscripts and in the form of iconographic, audio and film documents.

\section{INTRODUCTORY REMARKS}

There are various definitions of personal documents in the scientific literature ${ }^{1}$. One of these defines personal documents as "[...] documents that express the personal characteristics of their author in such a clear way that the reader can know his attitude to the events to which the document relates" (Sztumski, 2010, p. 208). Most often they include autobiographies, diaries, memoirs, letters, notes, interviews, confessions, written records of testimonies, drawings and photographs (Sztumski, 2010, p. 208; Leoński, 1995, pp. 123; Kłoskowska, 1972, pp. 79-83; Szczepański, 1973, pp. 624). These types of documents perform an extremely important function, among others in biographical research. They allow us not only to establish many facts concerning a person's life, but also contribute to learning about their character traits, sensitivity, disposition and views on a number of issues. They also help in explaining events in which they participated.

A widely understood document is the subject of a bibliography, provided that it is socially shared by means of reproduction. In the case of personal life documents, it often happens that they are not published in print. Therefore, the question arises whether personal life documents should be of interest to the bibliographic record and to what extent. The question posed is particularly important in the case of personal bibliographies, which, like personal life documents, are an irreplaceable source of information for biographical research.

Personal bibliographies are one of the few types of bibliographies whose authors strive for completeness in the selection of material (Hleb-Koszańska, 1948, pp. 3-4; Słodkowska \& Wilgat, 1963, pp. 313-318). This applies above all to personal primary bibliographies. These try to compile the author's entire creative output. In principle, they do not apply any restrictions in terms of the scope determined by the form of publishing and writing

\footnotetext{
${ }^{1}$ They are given by Jan Szczepański (1973, pp. 622-624).
} 
of the recorded works. They include non-serial publications, works, and bibliographic fragments. They combine scientific, popular-scientific and popular works, literary works, letters, speeches, appeals, scripts for films and theatrical plays, exhibition scenarios, musical compositions, songs and reviews. They register individual and co-authored works, editorial and publishing input, translations of works by other authors, voices in discussions, interviews and speeches. In addition to published works they include works prepared for printing, such as manuscripts, typescripts and archival materials. In addition to written documents, they also try to register other types of documents. They note iconographic, cartographic, audio-visual and sound materials, printed music, technical standards, patents, and recently also electronic documents.

These materials are of course not recorded in all personal bibliographies. Most of these are selected lists, often only of bibliographical materials. They apply selection both in terms of the subjects of the compiled documents as well as their types, forms of publishing and writing, language of publication, and place of publication.

Despite the high value of personal life documents in scientific research, the issue of their registration in personal bibliographies has not yet been addressed. They have been mentioned only marginally when discussing theoretical or methodological issues related to personal bibliography (Hleb-Koszańska, 1948, p. 3; Słodkowska \& Wilgat, 1963, p. 316). It seems to be an issue worth considering, if only because of the importance of this type of document for biographical research.

The research performed here does not claim to have exhausted the topic under consideration. Its character is only to survey and review and its purpose was to draw attention to the problem of selection of personal life documents in personal bibliographies. Efforts were made to show to what extent these have been interested in this type of material and how often they have include it. Also sought has been the answer to the question of what kinds of personal life documents are most often noted in the bibliographies analysed.

The main source material was collected based on retrospective Polish bibliographies of bibliographies which are current up to 1985. The analysis covered primary and secondary personal bibliographies as well as mixed primary-secondary lists, which were published as bibliographies sensu stricto in the form of non-serial publications and bibliographic works. However, bibliographic discussions, conditions of research and bibliographic attachments were omitted, because they are guided by their own criteria for the selection of material, usually other than bibliographical in the strict sense. The bibliographies thus collected were subjected to detailed research. They were analysed in terms of the selection of personal life documents. 


\section{SELECTION OF PERSONAL LIFE DOCUMENTS IN PERSONAL BIBLIOGRAPHIES}

The need to include personal life documents in personal bibliographies was noticed already at the beginning of the 19th century. This is confirmed by the compilation of works by the historian and creator of the Krzemieniecki Secondary School, Tadeusz Czacki, prepared by a teacher of the same school, Alojzy Osiński, published in the historical and literary monograph About Tadeusz Czacki's Life and Writings (Krzemieniec, 1816). In the bibliography, the author recorded the printed and manuscript works of the founder of "Volhynia's Athens". Among the printed works he included appeals and speeches given by Czacki, and among a group of manuscripts he noted his "Letters to the Most Important People in the Nation and Abroad" (Osiński, 1816, pp. 399-403). Osiński did not provide any further details about the letters, did not list them, did not specify the recipients of the correspondence and did not locate it. He only signalled that Czacki's correspondence was preserved in manuscript form.

The issue of completeness in the selection of material in personal bibliographies was noted in 1877 by Zygmunt Gloger, who came up with the idea for the preparation of a bibliography of Józef Ignacy Kraszewski, in connection with the jubilee of the 50th anniversary of the writer's creative work in 1879. Bibliography was to be one of the ways to celebrate this momentous event. Hence the man behind its inspiration believed that such a record should compile all types of documents, including the correspondence of the author of Stara baśń [An Ancient Tale] (Szczepański, 1881, p. 3). This sentiment was fully shared by Teodor Justyn Piekarski (Rola, 1878, p. 9). Karol Estreicher took up the preparation of the bibliography. On the occasion of the writer's jubilee, he prepared a list entitled Fifty Years of J.I. Kraszewski (1830-1879). An alphabetical and chronological compilation of the fifty years of the Jubilarian's scientific and literary activity, listing all editions of his works and translations into foreign languages (Kraków, 1879). In the bibliography he not only listed printed books, but also manuscripts and even announced works. However, he left out the writer's correspondence. It is difficult to determine why he did so - perhaps because of its abundance and dispersion.

At the same time, while Estreicher was working on his compilation of works by Kraszewski, another eminent Polish bibliographer, Władysław Wisłocki, published a personal bibliography of Grzegorz Piramowicz (Wisłocki, 1877, pp. 223-449; Zawodomski, 2014, pp. 101-102). Due to the fact that the list was to be a source of information helping in the preparation of the biography of this outstanding educator, Wisłocki attempted to collect all his works, both those printed and those remaining in manuscript form, including Piramowicz's letters addressed to various people, including Ignacy Potocki, Prince Adam Czartoryski, and Hugo Kołłątaj. 
A systematic registration of letters is contained in the personal bibliography of Adam Mickiewicz published in 1887-1898 in the pages of The Diary of the Adam Mickiewicz Literary Society, published in Lviv. One of the main tasks of this periodical was to collect and organise materials regarding the life and work of the Bard (Editors, 1887, p. V). To this end, a current primary bibliography of Mickiewicz began to be published in the pages of the magazine, starting with the first volume. Later authors, first Maurycy Stankiewicz and then Wilhelm Bruchnalski and Konstanty Wojciechowski, subsequently listed, among other things, published correspondence of the creator of Pan Tadeusz, setting aside a separate section for this (Stankiewicz, 1887, pp. 257-267; Stankiewicz, 1888, pp. 323-331; Stankiewicz, 1889, pp. 327-337; Stankiewicz, 1890, pp. 331-338; Bruchnalski, 1891, pp. 327-355; Wojciechowski, 1898, pp. 561-602).

Similar personal materials are included in the bibliography of Juliusz Słowacki, prepared by a seasoned bibliographer and literary historian, Wiktor Hahn. As a bibliography enthusiast and at the same time a researcher of Słowacki's life and work, he was fully aware of the importance of personal bibliographies in biographical research. That is why he undertook a bibliography of the poet. In 1901, he published the Bibliography on Juliusz Słowacki for 1899 (Hahn, 1901, pp. 3-38). In the selection of material, he tried to achieve the highest accuracy and completeness. As he states, "[...] in addition to separately published items, I included journals, magazines, calendars and other similar publications" (Hahn, 1901, p. 4). Among the various publishing and writing forms, the author also recorded editions of the poet's letters. Hahn continued his work, periodically publishing a "Review of the latest works about J. Słowacki" (for the years 1901-1915), published in the pages of Pamiętnik Literacki (1903-1914/1915). Here, he also compiled and characterized Słowacki's correspondence published during individual years.

In 1916 Hahn published a primary and secondary bibliography of Juliusz Słowacki (1916), prepared on the occasion of the 100th anniversary of the birth of the author of Balladyna in 1909. Like the previous lists, in the selection of material the author strived for completeness, which resulted in the collation of a total of 5,030 items. When collecting references, the bibliographer did not apply any restrictions in terms of author or territorial and linguistic coverage. He noted various forms of publishing, writing, and document types. He recorded non-serial publications, works, and bibliographic fragments. Included were letters, translations, and reviews. He described leaflets (posters, programs, invitations, entry tickets), sheet music, and iconographic documents (albums, portraits, drawings, photographs, postcards, stickers, medals, sculptures, monuments).

The bibliography was very well received by critics. Stefan Vrtel-Wierczyński, praising the published work, also drew attention to the comple- 
teness of the list. He stated that "[t]he author spared no effort to collect the material in the most exhaustive way and to put it in a clear and accurate picture" (S. V., 1917, p. 127). Stanisław Łempicki (1916, p. 4) spoke in a similar tone.

In the inter-war period, more personal bibliographies showing personal life documents appeared. An example may be the retrospective, primary and secondary bibliography of Nicolaus Copernicus by W. Bruchnalski (1924, pp. 209-246), created for the jubilee of the astronomer's 450th birthday in 1923. This model bibliography, according to critics, collected in the primary part works by the scientist (Gubrynowicz, 1924, p. 3). However, in the secondary part, he recorded correspondence addressed to his person as well as medals and portraits of the astronomer.

Also Ludwik Stolarzewicz, the author of three personal bibliographies, two of which he devoted to Mickiewicz (Stolarzewicz, 1924a; Stolarzewicz, 1924c) and one to Zygmunt Krasiński (Stolarzewicz, 1924b), equipped his lists with a register of personal life documents of both poets. In Krasiński's bibliography, he compiled diaries and letters written by the creator of Nieboska Komedia [The Un-Divine Comedy] and university documents related to him. Also in both bibliographies of Mickiewicz he included letters, the only difference being that in the secondary list he described the letters addressed to the author of Dziady [Forefathers' Eve], and in the primary list he included, apart from correspondence, also the speeches given by the poet. The degree of completeness of both bibliographies of Mickiewicz, including the selection of letters, was criticized by reviewers, who pointed out the numerous deficiencies in the recorded material. Critics also pointed to the author's factual errors and unreliable analysis of sources (Pigoń, 1924a, pp. 229-244; Pigoń, 1924b, p. 4; Semkowicz, 1924/1925, pp. 461-474).

Among the bibliographies published in the interwar period, one can indicate compilations that included sound documents - innovative for that time. An example may be the secondary bibliography of Oswald Balzer, the researcher of the system and law of the old Poland. It contains a lecture devoted to the historian given on Polish Radio by the eminent medievalist Stanisław Zakrzewski (Dąbkowski, 1934, p. 221; Zawodomski, 2004a, p. 158).

As a result of the dynamic development of personal bibliographies after World War II, the number of personal life documents recorded in them also increased. This can be seen already in the first bibliographies published shortly after the war. In 1949, an extensive Bibliography of F.F. Chopin, prepared by Bronisław Edward Sydow, was published by the Warsaw Scientific Society. The number of entries listed in it (8,700 items), as well as the supplement published in 1954 (Sydow, 1954), testify to the fact that the author wanted to provide users with comprehensive research material. 
Sydow also did not omit the composer's personal documents. Among the works useful for future biographers of Fryderyk Chopin he included letters, notes, autographs of works, memoirs, and diaries, including not only printed works but also those remaining in manuscript form.

The broad criteria for material selection adopted by Sydowa were truncated in the Chopin Bibliography 1849-1969 (Kraków, 1970), compiled by Kornel Michałowski. The author had come to the correct conclusion that "[ $t$ ]he assumption of achieving 'completeness' in bibliographies - including personal ones such as Chopin's bibliography - is [...] impossible to obtain, especially when it comes to written works produced for over a hundred years on a global scale, and above all even pointless as regards the adopted functional goals. The bibliography [...] includes [...] Chopin literature selected in terms of its importance and value, both documentary and historical, scientific and musicological, as well as for cognitive or popularizing values "(K.M., 1970, p. 11). Despite the selection used, Michałowski did not forgo recording the composer's published letters, his manuscripts found and identified, as well as diaries and memories about the life and work of Chopin.

Michałowski applied the principles of material selection and choice that he had introduced in the current bibliography of Chopin, which he prepared and regularly published in the "Chopin Annual", collating literature since 1970 (Michałowski, 1975, pp. 121-176; Michałowski, 1978, pp. 115-171; Michałowski, 1979, pp. 225-234; Michałowski, 1981, pp. 131-139; Michałowski, 1982, pp. 61-76; Michałowski, 1983, pp. 171-182; Michałowski, 1984, pp. 153-163). The only difference was that the author strove for greater completeness in this list.

The Institute of Literary Research (IBL), operating since 1948, has made a significant contribution to the development of personal bibliographies. A whole series of personal bibliographies of eminent Polish writers and poets were created in this scientific institution. They are often monumental bibliographic or bio-bibliographic monographs (Bajor, 2003, pp. 113114). According to the methodological assumptions developed in the IBL, the authors of the bibliography aimed for completeness in the selection of materials, both in the primary and secondary parts (Podstawowe wytyczne monografii bibliograficznej [Basic Guidelines for Bibliographic Monographs], 1955, pp. 483-492).

An example would be Jadwiga Czachowska's doctoral dissertation entitled Gabriela Zapolska. Bio-bibliographic monograph (Kraków, 1966). According to a reviewer, the work, referred to as the "fundamental work", is "[...] a full bibliography of Zapolska's writing" (Weiss, 1967, p. 358). Among the many different works of the author of Moralność pani Dulskiej [The Morality of Mrs. Dulska], and numerous works concerning her, Czachowska also compiled, in the form of separate lists, letters of the writer to 
various people, both published and remaining in manuscript form, as well as interviews she gave.

Janusz Stradecki adopted a different principle in relation to the registration of epistolographic materials in the work Julian Tuwim. Bibliography (Warszawa, 1959). He included only the part of the poet's correspondence that was published during his lifetime ("Introduction", 1959, pp. 14-15). Among other personal documents, he noted printed interviews, speeches, appeals, and declarations by Tuwim.

A selective approach to correspondence is also featured in bio-bibliographical monographs such as Tadeusz Żeleński (Boy). Creativity and life (Warszawa, 1967), developed by Barbara Winklowa, and The work of Wtadysław Broniewski (Warszawa, 1973) by Feliksa Lichodziejewska. The author of the first of these works did not include manuscript letters at all, and limited the selection of published correspondence. In addition, she omitted unpublished lectures and speeches by Boy-Żeleński. On the other hand Lichodziejewska strived for the greatest possible completeness in the selection of materials, trying to include all the works of Broniewski printed and preserved in manuscript, including the unpublished Diary, but from the rich correspondence she chose only the published private letters of the poet. The rules governing the selection introduced in these bibliographies of Tuwim and Boy-Żeleński did not gain the approval of reviewers (Kądziela, 1961, p. 240; Stradecki, 1970, pp. 377, 390).

Monumental bibliographic monographs of the greatest Polish writers are being published to this day as separate volumes or parts created in the IBL's Bibliography of Polish literature "Nowy Korbut" (Czachowska, 1979, pp. 164-186). A bibliography of Kraszewski has appeared during the period under examination (Stupkiewicz, Śliwińska \& Roszkowska-Sykałowa, 1966), and that of Bolesław Prus (Tyszkiewicz, 1981). Each of these includes printed and manuscript correspondence of both writers. In the first one it is "[...] given only in a small fraction of letters [...] found in larger Polish libraries" (Authors, 1966, p. 7), whereas in the second, "[e]ach letter is listed in chronological order - separately in one group in which Prus is the sender and in one group in which he is the addressee" (Maciejewski, 1981, p. 7). The bibliographic outline for Kraszewski also compiles unprinted diaries from school and university years, notes, various types of contracts, an autobiography and the writer's published will. Similar materials are included in the bibliography of Prus. In addition, his bibliography records reminiscences about the author of Lalka [The Doll], his birth certificate, school reports, testament, and letters addressed to as well as written by his wife, Octavia.

A bibliography of Andrzej Frycz Modrzewski (Andrzej Frycz Modrzewski, 1962) also relied on the so-called "Korbut Block". Materials useful to biographers of the author of the treatise De Republica emendanda [On the 
Repair of the Commonwealth] included manuscripts and printed works, such as the autographs of his works, correspondence, including the writer's letters, letters addressed to Modrzewski and letters regarding him as well as other biographical documents. Although this is not a complete bibliography, in the reviewer's opinion ,,[i]t is an indispensable help and a basic source for the future monographer" (stg, 1963, p. 301).

Maria Stokowa, the author of the four-part bibliographic monograph of Stanisław Wyspiański, published with the 15th edition of the Collected Works of this playwright, poet, and painter (Stokowa, 1967-1968), also used materials collected in the IBL documentation laboratories. Wanting to present the fullest possible picture of the author of Wesele [The Wedding] and the literature on it, Stokowa took into account, among other things, personal documents of the poet, including manuscript autographs of works and letters by Wyspiański saved from the war. She also recorded accounts of the playwright's interviews and memoirs devoted to him.

Personal writers' documents have been recorded not only in monumental book publications, but also in smaller bibliographic publications. An example may be the primary-secondary bibliography of Witold Gombrowicz (Biłek-Dąbrowska, 1984, pp. 743-840). In the primary part, the list includes letters, interviews, and the diary of the author of Ferdydurke, while the secondary section compiles interviews and memoirs concerning the writer. In turn, in the bibliography of Julian Przyboś, in addition to the poet's correspondence and memories of him, a film and a sound recording about him were noted (Sokół, 1976, p. 361).

Personal life documents have also been included in the personal bibliographies of academics. These mainly record interviews with scholars but also often list manuscripts and typescripts of their scientific works and lectures given. However, one can cite bibliographies that cover a much broader spectrum of documents analysed.

An example would be the bibliography of Joachim Lelewel (Hleb-Koszańska \& Kotwiczówna, 1952). The authors, striving for completeness in registering the historian's printed works, included his letters, notes, diary, will, and numerous speeches and appeals (Zawodomski, 2004a, p. 152).

Henryk Baranowski, the author of the two-part retrospective primary-secondary bibliography of Nicolaus Copernicus, followed an analogous criteria of material selection. $(1958 ; 1973)$. In both extensive works, the author included exclusively printed works. Among them were letters of Copernicus and those written to him, printed information about the astronomer's manuscripts, and other documents about his life.

Even more varied personal documents are contained in the bibliography of the law historian and researcher on the history of the Slavs, Wacław Aleksander Maciejowski, written by Stanisław Borowski (1959). The author intended to develop a biography of the scholar. For this purpose, he 
prepared a listing showing all materials useful for the implementation of the task, which included in the bibliography all printed and manuscript works as well as archival materials. He recorded, among others, documents from university days and professional work, a biography, diary, notes, and correspondence of the scholar, including letters written by him, addressed to him, and containing references to him.

This accumulation of examined documents, printed and in manuscript form, is also found in the bibliography of the eminent Polish geographer Wacław Nałkowski (Babicz, 1962, pp. 81-166). Among them, similarly to the bibliography of Maciejowski, one can find letters and source materials from the period of his studies (including an ID card, secondary school graduation certificate, index, lessons, and lecture notes), as well as autobiographies, his marriage certificate and family papers pertaining to Nałkowski's ancestors. A bibliography of Kazimierz Wyka is also characterized by broad material selection criteria (Głowacka \& Grabowska, 1978, pp. 447-571). It includes, among other things, medals and prizes awarded to the distinguished historian and critic of Polish literature.

The systematic registration of personal life documents is observed in a large part of the bibliographies of socio-political activists, especially those that were published in the quarterly "Z Pola Walki." This periodical was supposed to contain, as stated by its founders, "[...] a permanent, special bibliographical section pertaining to activists of the Polish workers' movement " "From the editorial office", 1958, p. 4). The bibliographies published in this section have often listed printed and manuscript sources of an autobiographical and memorial nature, correspondence of individual activists, and their speeches and lectures (Tomicki, 1958, pp. 231-240; Kalicka, 1958, pp. 298-321; Jakubowski, 1959 , pp. 196-207; Iwański, 1973, pp. 260-272).

A large number of speeches and other public appearances are listed in the bibliography of the PPS activist and Member of the Sejm (1919-1933) Norbert Barlicki (Tomicki, 1964, pp. 331-364). The Bibliography of Julian Marchlewski, prepared by Jadwiga Kaczanowska, in addition to a speech recorded on a gramophone record, lists unpublished letters and manuscripts of Marchlewski. The bibliography of Janusz Korczak is similar (Ciesielska, 1985). It registers the manuscript correspondence of this social activist, teacher and publicist, notes unpublished texts by Korczak as well as unreleased materials and documents devoted to him.

\section{SUMMARY}

Personal bibliographies published in Poland until 1985 register various types of personal life documents. However, this is not a common phenomenon. The vast majority of the lists analysed omit such materials. 
Among the personal life documents compiled in personal bibliographies, various forms of written documents dominate. Letters, diaries, memoires, diaries, interviews, and autobiographies are most frequently noted. In addition, iconographic, audio, and film documents are described, although very rarely.

The bibliographies examined include personal life documents most often when they are published. It is relatively rare for them to be shown in unpublished form. Registration of manuscripts is of course not a basic obligation of the bibliography. It should also be added that collecting such documents is not easy. Searching for them requires a lot of work and effort on the part of bibliographers, because they are usually scattered around various institutions, in the possession of private individuals, sometimes protected by various rights, and often found abroad. From a scientific point of view, especially in terms of biography, these are materials of great value. Therefore, personal bibliographies should more closely record personal life documents remaining in manuscripts.

\section{BIBLIOGRAPHY}

Andrzej Frycz Modrzewski. Bibliografia zestawiona przez Pracownię Bibliografii Staropolskiej Instytutu Badań Literackich (1962). Wrocław: Zakład Narodowy im. Ossolińskich.

Babicz, Józef (1962). „Materiały do biografii i bibliografii Wacława Nałkowskiego”. In: Wacław Nałkowski. W pieććdziesiąta rocznicę zgonu. Pr. collection. Edited by B. Olszewicz. Warszawa: Państwowe Wydaw. Naukowe, pp. 81-166.

Bajor, Agnieszka (2003). Monografia bibliograficzna: analiza modelowa. Częstochowa: Wydaw. „e-media”.

Baranowski, Henryk (1958). Bibliografia kopernikowska 1509-1955. Warszawa: Państwowe Wydaw. Naukowe.

Baranowski, Henryk (1973). Bibliografia kopernikowska. [Vol.] 2: 1956-1971. Warszawa: Państwowe Wydaw. Naukowe.

Biłek-Dąbrowska, Zofia (1984). „Materiały do bibliografii twórczości Witolda Gombrowicza." In: Gombrowicz i krytycy. Selection and development: Z. Łapiński. KrakówWrocław: Wydaw. Literackie, pp. 743-840.

Borowski, Stanisław (1959). Maciejowskiana. Materiały do biografii Wacława Aleksandra Maciejowskiego. Wrocław: Państwowe Wydaw. Naukowe.

Bruchnalski, Wilhelm (1924). „Bibliografia Kopernikowska 1509-1923.” In: Mikołaj Kopernik. Księga zbiorowa. Lwów: Książnica Polska Towarzystwa Nauczycieli Szkół Średnich i Wyższych, pp. 209-246.

Bruchnalski, Wilhelm (1891). „Bibliografia o Adamie Mickiewiczu za rok 1890”. Pamiętnik Towarzystwa Literackiego imienia Adama Mickiewicza, vol. 5, pp. 327-355.

Ciesielska, Marta, ed. (1985). Janusz Korczak. Bibliografia 1896-1942. Heinsberg: Agentur Dieck.

Czachowska, Jadwiga (1979). Rozwój bibliografii literackiej w Polsce. Wrocław: Zakład Narodowy im. Ossolińskich. 
Dąbkowski, Przemysław (1934). „Bibliografia.” In: Oswald Balzer. Życie i dzieła (1858-1933). Lwów: Towarzystwo Naukowe, pp. 215-221.

Editors (1887). „Słowo wstępne." Pamiętnik Towarzystwa Literackiego imienia Adama Mickiewicza, vol. 1, pp. V-VII.

Głowacka, Zofia; Grabowska, Marta (1978). „Bibliografia podmiotowo-przedmiotowa Kazimierza Wyki za lata 1930-1975." In: Kazimierz Wyka. Charakterystyki, wspomnienia, bibliografia. Collective work edited by: H. Markiewicz, A. Fiut. Kraków: Wydaw. Literackie, pp. 447-571.

Gubrynowicz, Bronisław (1924). „Kopernikiana. (Review) Bruchnalski W. Bibliografia Kopernikowska 1509-1923." Kurier Warszawski Vol. 104, no. 114, pp. 3-4.

Hahn, Wiktor (1901). „Bibliografia o Juliuszu Słowackim za rok 1899.” Pamiętnik Naukowy i Literacki, vol. 29, pp. 3-38.

Hahn, Wiktor (1916). Bibliografia o Juliuszu Słowackim za rok 1909. Lwów: Nakł. Komitetu Obchodu Setnej Rocznicy Urodzin Juliusza Słowackiego we Lwowie.

Hleb-Koszańska, Helena (1948). „Wytyczne bibliografii Joachima Lelewela. (Z problemów bibliografii osobowej)". Biuletyn Państwowego Instytutu Ksiażki, vol. 1, no. 5, pp. 1-12.

Hleb-Koszańska, Helena; Kotwiczówna, Maria, ed. (1952). Bibliografia utworów Joachima Lelewela. Wrocław: Zakład Narodowy im. Ossolińskich.

Iwański, Gereon (1973). „Bibliografia prac Stanisława Łańcuckiego”. Z Pola Walki, vol. 16, no. 2/3, pp. 260-272.

Jakubowski, Józef (1959). „Bibliografia prac Franciszka Fiedlera”. Z Pola Walki, vol. 2, no. 4, pp. 196-207.

K.M. [Michałowski, Kornel] (1970). „Od autora”. In: Michałowski K: Bibliografia chopinowska 1949-1969. Kraków: Polskie Wydaw. Muzyczne, pp. 11-15.

Kalicka, Felicja, ed. (1958). „Bibliografia prac Juliana Leszczyńskiego-Leńskiego”. Z Pola Walki, vol. 1, no. 4, pp. 298-321.

Kądziela, Jerzy (1961). (Review) „Stradecki J. Julian Tuwim. Bibliografia.” Pamiętnik Literacki, Vol. 52, no. 1, pp. 231-245.

Kłoskowska, Antonia (1972). „Rodzaje dokumentów osobistych”. In: Ruch pamiętnikarski i przemiany kultury polskiej. Warszawa: Państwowe Wydaw. Naukowe, pp. 79-83.

Leoński, Jacek (1995). „Historia wykorzystania dokumentów osobistych w socjologii”. Ruch Prawniczy Ekonomiczny i Socjologiczny, vol. 57, no. 2. pp. 123-128.

Łempicki, Stanisław (1916). „Jubileuszowa bibliografia o Słowackim. (Review) Hahn W. Bibliografia o Juliuszu Słowackim za rok 1909". Kurier Lwowski, vol. 34, no. 519, pp. 4.

Maciejewski, Jarosław (1981). „Wstęp”. In: Bolesław Prus (Aleksander Głowacki). T. Tyszkiewicz, ed. Bibliografia literatury polskiej „Nowy Korbut”, vol. 17, no. 1. Warszawa: Państwowy Instytut Wydawniczy, pp. 5-7.

Michałowski, Kornel, ed. (1975). „Bibliografia chopinowska 1970-1973”. Rocznik Chopinowski, vol. 9, pp. 121-176.

Michałowski, Kornel, ed. (1978). „Bibliografia chopinowska 1974-1977, wraz z uzupełnieniami za lata 1970-1973". Rocznik Chopinowski, vol. 11, pp. 115-171.

Michałowski, Kornel, ed. (1979). „Bibliografia chopinowska 1978, wraz z uzupełnieniami za lata 1974-1977". Rocznik Chopinowski, vol. 12, pp. 225-234.

Michałowski, Kornel, ed. (1981). „Bibliografia chopinowska 1979”. Rocznik Chopinowski, Vol. 13, pp. 131-139.

Michałowski, Kornel, ed. (1982). „Bibliografia chopinowska 1980”. Rocznik Chopinowski, vol. 14, pp. 61-76. 
Michałowski, Kornel, ed. (1983). „Bibliografia chopinowska 1981”. Rocznik Chopinowski, vol. 15, pp. 171-182.

Michałowski, Kornel, ed. (1984). „Bibliografia chopinowska 1982, wraz z uzupełnieniami za lata poprzednie". Rocznik Chopinowski, vol. 16, pp. 153-163.

„Od redakcji” (1958). Z Pola Walki, vol. 1, no. 1, pp. 3-6.

Osiński, Alojzy (1816). [List of Tadeusz Czacki's works]. In: Osiński A. O życiu i pismach Tadeusza Czackiego. Krzemieniec: [no publisher given], pp. 399-403.

Pigoń, Stanisław (1924a). (Review) „Stolarzewicz L. Bibliografia Mickiewiczowska; Stolerzewicz L. Bibliografia pism Mickiewicza". Przeglad Warszawski, no. 38, pp. 229-244.

Pigoń, Stanisław (1924b). (Review) „Stolarzewicz L. Bibliografia pism Mickiewicza”. Dziennik Wileński, vol. 8, no. 57, p. 4; vol. 8, no. 61, p. 4.

„Podstawowe wytyczne monografii bibliograficznej” (1955). Pamiętnik Literacki, vol. 46, no. 3/4, pp. 483-492.

Rola, Teodor, Justyn [Piekarski, Teodor, Justyn] (1878). Józef Ignacy Kraszewski. Z powodu pięćdziesięciolecia pracy $i$ zastug jego dla społeczeństwa. Warszawa: Drukiem Józefa Ungra.

S.V. [Vrtel-Wierczyński, Stefan] (1917). (Review) „Hahn W. Bibliografia o Juliuszu Słowackim za rok 1909". Rok Polski, vol. 2, no. 5/6, pp. 126-127.

Semkowicz, Aleksander (1924/1925). (Review) „Stolarzewicz L. Bibliografia pism Mickiewicza; Stolarzewicz L. Bibliografia Mickiewiczowska". Pamiętnik Literacki, vol. 21, pp. 461-474.

Słodkowska, Elżbieta; Wilgat, Janina (1963). „Bibliografia osobowa”. In: Metodyka bibliograficzna. Poradnik dla autorów bibliografii specjalnych. Collective work edited by H. Hleb-Koszańskiej, M. Dembowskiej and H. Sawoniaka. Warszawa: Wydaw. SBP, pp. 313-344.

Sokół, Zofia (1976). „Bibliografia twórczości literackiej Juliana Przybosia i opracowań o jego życiu i dorobku literackim (za lata 1922-1972)". In: Julian Przyboś. Życie i dzieło poetyckie. Edited by S. Fryciego. Rzeszów: Towarzystwo Naukowe, pp. 227-368.

Stankiewicz, Maurycy (1887). „Bibliografia o Adamie Mickiewiczu za rok 1886”. Pamiętnik Towarzystwa Literackiego imienia Adama Mickiewicza, vol. 1, pp. 257-267.

Stankiewicz, Maurycy (1888). „Bibliografia o Adamie Mickiewiczu za rok 1887”. Pamiętnik Towarzystwa Literackiego imienia Adama Mickiewicza, vol. 2, pp. 323-331.

Stankiewicz, Maurycy (1889). „Bibliografia o Adamie Mickiewiczu za rok 1888”. Pamiętnik Towarzystwa Literackiego imienia Adama Mickiewicza, vol. 3, pp. 327-337.

Stankiewicz, Maurycy (1890). „Bibliografia o Adamie Mickiewiczu za rok 1889”. Pamiętnik Towarzystwa Literackiego imienia Adama Mickiewicza, vol. 4, pp. 331-338.

stg. [Grzeszczuk, Stanisław] (1963). (Review) „Andrzej Frycz Modrzewski. Bibliografia”. Ruch Literacki, vol. 4, no. 5/6, pp. 300-301.

Stokowa, Maria (1967-1968). Stanisław Wyspiański. Monografia bibliograficzna, vol. 1: Twórczość pisarska. Życiorys; vol. 2: O twórczości pisarskiej i plastycznej; vol. 3-4: Teatr Wyspiańskiego. Kraków: Wydaw. Literackie.

Stolarzewicz, Ludwik (1924a). Bibliografia Mickiewiczowska. Wilno: Nakł. i druk Ludwika Chomińskiego.

Stolarzewicz, Ludwik (1924b). Bibliografia o Krasińskim. Wilno: P. Hniadziewicz.

Stolarzewicz, Ludwik (1924c). Bibliografia pism Mickiewicza. Wilno: P. Hniadziewicz.

Stradecki, Janusz (1970). (Review) „Winklowa B. Tadeusz Żeleński (Boy). Twórczość i życie." Pamiętnik Literacki, vol. 61, no. 1, pp. 376-400. 
Stupkiewicz, Stanisław; Śliwińska, Irmina; Roszkowska-Sykałowa, Wanda] (1966). „Wstęp." In: Józef Ignacy Kraszewski. Zarys bibliograficzny. Bibliografia literatury polskiej "Nowy Korbut". vol. 12. Kraków: Wydaw. Literackie, pp. 5-10.

Stupkiewicz, Stanisław; Śliwińska, Irmina; Roszkowska-Sykałowa, Wanda, ed. (1966). Józef Ignacy Kraszewski. Zarys bibliograficzny. Bibliografia literatury polskiej „Nowy Korbut”. vol. 12. Kraków: Wydaw. Literackie.

Sydow, Bronisław, Edward (1954). Bibliografia F.F. Chopina. Suplement. Warszawa: Państwowe Wydaw. Naukowe.

Szczepański, Alfred (1881). „Rok jubileuszowy”. In: Księga pamiatkowa jubileuszu J.I. Kraszewskiego 1879 roku. Kraków: Nakład Komitetu Wydawniczego, pp. 1-22.

Szczepański, Jan (1973). Odmiany czasu teraźniejszego. Warszawa: Książka i Wiedza.

Sztumski, Janusz (2010). Wstęp do metod i technik badań społecznych. Katowice: „Śląsk”.

Tomicki, Jan (1958). „Bibliografia artykułów Edwarda Próchniaka”. Z Pola Walki, vol. 1, no. 4, pp. 231-240.

Tomicki, Jan (1964). „Bibliografia prac Norberta Barlickiego”. In: Barlicki N. Wybór przemówień $i$ artykułów z lat 1918-1939. Warszawa: Książka i Wiedza, pp. 331-364.

Tyszkiewicz, Teresa, ed. (1981). Bolesław Prus (Aleksander Głowacki). Bibliografia literatury polskiej „Nowy Korbut”. vol. 17, no. 1. Warszawa: Państwowy Instytut Wydawniczy.

Weiss, Tomasz (1967). (Review) „Czachowska J. Gabriela Zapolska. Monografia bio-bibliograficzna". Ruch Literacki, vol. 8, no. 6, pp. 358-360.

Wisłocki, Władysław (1877). „Poczet chronologiczny prac drukowanych i rękopiśmiennych Grzegorza Piramowicza". Rozprawy i Posiedzenia Wydziału Filologicznego Akademii Umiejętności, vol. 5, pp. 223-449.

Wojciechowski, Konstanty (1898). „Bibliografia o Adamie Mickiewiczu za rok 1891-1897”. Pamiętnik Towarzystwa Literackiego imienia Adama Mickiewicza, vol. 6, pp. 561-602.

„Wstęp" (1959). In: Stradecki J. Julian Tuwim. Bibliografia. Warszawa: Państwowy Instytut Wydawniczy, pp. 5-16.

Znajomski, Artur (2004a). Bibliografie osobowe historyków polskich. Lublin: Wydaw. Uniwersytetu Marii Curie-Skłodowskiej.

Znajomski, Artur (2004b). „Bibliografie specjalne - tendencje rozwoju na przykładzie bibliografii osobowych". In: Piąta Ogólnokrajowa Narada Bibliografów, Warszawa 11-13 czerwca 2003. Referaty i dyskusja. Warszawa: Biblioteka Narodowa, pp. 213-228.

Znajomski, Artur (2014). „Władysław Wisłocki jako bibliograf”. In: Kraków-Lwów. Biblioteki XIX-XX wieku. Edited by A. Ruty, E. Wójcik. Kraków: Księgarnia Akademicka, pp. 91-107.

Artykuł w wersji poprawionej wptyną do Redakcji 30 sierpnia 2019 r. 
ARTUR ZNAJOMSKI

Instytut Informacji Naukowej i Bibliotekoznawstwa

UMCS w Lublinie

e-mail: aznajomski@o2.pl

\section{DOKUMENTY ŻYCIA OSOBISTEGO W BIBLIOGRAFIACH OSOBOWYCH. REKONESANS BADAWCZY}

SŁOWA KLUCZOWE: Bibliografie osobowe. Dobór materiału. Dokumenty życia osobistego. Historia.

ABSTRAKT: Tezy/cel artykułu - Zasadniczym celem artykułu jest przedstawienie doboru dokumentów życia osobistego w bibliografiach osobowych, wydanych w Polsce do $1985 \mathrm{r}$. Metody badań - Zastosowano metodę analizy i krytyki bibliografii osobowych, zwracając uwagę na dobór materiału, a w szczególności na rejestrację dokumentów życia osobistego. Wyniki i wnioski - Podjęte badania dowodza, że bibliografie osobowe, opublikowane do 1985 r., uwzględniają różnego typu dokumenty życia osobistego, ale czyni tak tylko niewielka ich część. Zdecydowana większość analizowanych zestawień pomija tego rodzaju dokumenty, choć są one niezmiernie istotnym źródłem informacji w badaniach naukowych. Chętnie z nich korzysta m.in. biografistyka. Bibliografie osobowe powinny w znacznie większym stopniu rejestrować dokumenty życia osobistego i to nie tylko te, które są opublikowane, ale też pozostające $\mathrm{w}$ rękopisach oraz występujące $\mathrm{w}$ formie dokumentów ikonograficznych, dźwiękowych i filmów. 